\title{
Microbial dynamics in RAS water: Effects of adding acetate as a biodegradable carbon-
} source

Rojas-Tirado, Paula Andrea; Pedersen, Per Bovbjerg; Vadstein, Olav; Pedersen, Lars-Flemming

Published in:

Aquacultural Engineering

Link to article, DOI:

10.1016/j.aquaeng.2018.12.010

Publication date:

2019

Document Version

Peer reviewed version

Link back to DTU Orbit

Citation (APA):

Rojas-Tirado, P. A., Pedersen, P. B., Vadstein, O., \& Pedersen, L-F. (2019). Microbial dynamics in RAS water: Effects of adding acetate as a biodegradable carbon-source. Aquacultural Engineering, 84, 106-116. https://doi.org/10.1016/j.aquaeng.2018.12.010

\section{General rights}

Copyright and moral rights for the publications made accessible in the public portal are retained by the authors and/or other copyright owners and it is a condition of accessing publications that users recognise and abide by the legal requirements associated with these rights.

- Users may download and print one copy of any publication from the public portal for the purpose of private study or research.

- You may not further distribute the material or use it for any profit-making activity or commercial gain

- You may freely distribute the URL identifying the publication in the public portal 


\section{Accepted Manuscript}

Title: Microbial dynamics in RAS water: Effects of adding acetate as a biodegradable carbon-source

Authors: Paula Rojas-Tirado, Per Bovbjerg Pedersen, Olav Vadstein, Lars-Flemming Pedersen

PII:

DOI:

Reference:

To appear in:

Received date:

Accepted date:
S0144-8609(18)30179-1

https://doi.org/10.1016/j.aquaeng.2018.12.010

AQUE 1979

\section{Aquacultural Engineering}

19 December 2018

20 December 2018

Please cite this article as: Rojas-Tirado P, Pedersen PB, Vadstein O, Pedersen L-Flemming, Microbial dynamics in RAS water: Effects of adding acetate as a biodegradable carbon-source, Aquacultural Engineering (2018), https://doi.org/10.1016/j.aquaeng.2018.12.010

This is a PDF file of an unedited manuscript that has been accepted for publication. As a service to our customers we are providing this early version of the manuscript. The manuscript will undergo copyediting, typesetting, and review of the resulting proof before it is published in its final form. Please note that during the production process errors may be discovered which could affect the content, and all legal disclaimers that apply to the journal pertain. 


\title{
Microbial dynamics in RAS water: Effects of adding acetate as a biodegradable carbon-source.
}

\author{
Paula Rojas-Tirado ${ }^{a, b *}$, Per Bovbjerg Pedersen ${ }^{a}$, Olav Vadstein ${ }^{c}$, Lars-Flemming Pedersen ${ }^{a}$. \\ aDTU Aqua, Technical University of Denmark, Section for Aquaculture, The North Sea Research Centre, P.O. Box 101, DK-9850 Hirtshals, Denmark. \\ ${ }^{b}$ NIVA, Norwegian Institute for Water Research, Section for Aquaculture, Thormøhlensgate 53D, 5006 Bergen, Norway. \\ 'NTNU, Norwegian University of Science and Technology, Department of Biotechnology and Food Science, N-7491 Trondheim, Norway. \\ *Corr. author e-mail address: par@niva.no
}

\section{HIGHLIGHTS}

[Rojas-Tirado et al., "Microbial dynamics in RAS water: Effects of adding ..."]

- Bacterial activity and abundance increased immediately after acetate addition to RAS water in beakers.

- Bacterial activity remained constant in the water phase after acetate spike in RAS with submerged biofilter.

- Submerged biofilters have a high capacity to attenuate fluctuations of organic matter in RAS.

\begin{abstract}
This study evaluated the effect of an abrupt increase in easily biodegradable carbon (acetate) on bacterial activity and abundance in the water of recirculating aquaculture systems (RAS). The study included a batch experiment with RAS water only, and an experiment at system level where twelve pilot scale RAS were used. The batch experiment was made to test how acetate concentration would influence the microbial state in RAS water. Further, we wanted to observe if the selected microbial analysis tools would be able to detect these changes. The second experiment was carried out in twelve identical and independent RAS that had been operated under constant loading conditions $\left(1.6 \mathrm{~kg} / \mathrm{m}^{3}\right.$ make-up water) for five months prior to the trial. The twelve RAS were divided into four treatment groups in triplicates: i) control with submerged biofilter (Ctrl+bf); ii) control without submerged biofilter (Ctrl-bf); iii) acetate addition in RAS with submerged biofilter (Ac+bf); and iv) acetate addition in RAS without submerged biofilter (Ac-bf). The biofilter media from the groups without submerged biofilter (Ac-bf and Ctrl-bf) was removed just $5 \mathrm{~h}$ prior to the start of the trial. The two acetate treatment groups (Ac+bf and Ac-bf) were spiked with $40 \mathrm{mg} / \mathrm{L}$ of acetate three consecutive times $(0,24$ and $48 \mathrm{~h})$. Consumption of acetate, bacterial abundance and bacterial activity were followed for 72 hours after the first acetate spike for both experiments. Bacterial activity was quantified by BactiQuant ${ }^{\circledR}$ and hydrogen peroxide (HP) degradation assay. Bacterial abundance was assessed by quantifying micro-
\end{abstract}


particles and free-living bacteria. In the batch experiment we observed a significant increase in bacterial activity proportional to the amount of acetate added, and a corresponding significant increase in microparticles (1-3 $\mu \mathrm{m})$. In the pilot scale RAS experiment, the acetate addition in RAS with submerged biofilter did not cause an increase in bacterial activity, or in the number of microparticles in the water phase but a significant increase in bacterial activity and number of microparticles were observed in the RAS without submerged biofilter (Ac-bf). These changes were particularly pronounced shortly after each acetate spike.

In RAS with submerged biofilters, the acetate was presumably consumed primarily by the bacterial community within the biofilm, and consequently, only minor changes were observed in densities of freeliving bacteria in the water phase. The results of the study suggest that heterotrophic bacteria in the submerged biofilter have a high capacity to handle fluctuation of organic matter loading in RAS, thereby stabilizing the abundance and activity of bacteria in the water column.

Keywords: bacterial activity, substrate, hydrogen peroxide degradation, BactiQuant ${ }^{\circledast}$, recirculating aquaculture system (RAS), acetate.

\section{Introduction}

In recirculating aquaculture systems (RAS), the biofilter and the water are the two major environments for microbes (Blancheton et al., 2013). In the biofilter, bacteria live attached to the biomedia surface, while in the water, bacteria live as free-living bacteria, bacterial aggregates or attached to particles. The bacteria in the water are those interacting directly with the rearing organism and other micro-particles (Blancheton et al., 2013; Fernandes, 2015). Both environments have a delimited carrying capacity (CC), which is set by the amount of substrate restricting the number of microbes that can be sustained within a system over time (Vadstein et al., 1993). In RAS, several factors such as feed spill, insufficient solids removal and moribund fish can increase the CC and, potentially, affect the microbial water quality (Attramadal et al. 2012, 2016; Wold et al., 2014). These effects might be reflected by changes in bacterial abundancy, activity and diversity.

The majority of bacterial populations in RAS are heterotrophic communities (Leonard et al., 2000; Michaud et al., 2009; Michaud et al., 2014; Rud et al., 2017; Gonzalez-Silva et al., 2016). These bacteria obtain their energy by degrading dissolved and particulate organic matter (Polanco et al., 2000; Bitton, 2011). Of the macro elements required by bacteria (carbon, nitrogen and phosphorus), carbon (organic matter) is often the growth-limiting compound within RAS (Leonard et al., 2000). Therefore, it can be hypothesized that an increase in the supply of biodegradable organic matter in RAS water will increase the CC and consequently cause an increase in activity and abundance of heterotrophic bacteria. Concentrations as low as $1 \mu \mathrm{g} \mathrm{C} / \mathrm{L}$ of assimilable dissolved organic carbon have been shown to be enough to promote bacterial growth of $10^{3}-$ $10^{4}$ cells/ml (reviewed in Prest et al. 2016).

Several studies have proposed that an organic carbon to nitrogen ratio $(C / N)$ close to one provides a stable balance between autotrophic and heterotrophic bacteria communities in the biofilter (Avnimelech, 1999; Zhu and Chen, 2001; Nogueira et al., 2002; Michaud et al., 2006). The C/N ratio realized will depend on feed composition, feed digestibility (Michaud et al., 2014) and the efficiency of treatment units for the removal of 
organic matter (Fernandes et al., 2015). Biofilters in RAS ensure the turnover of ammonia, but also interfere with the organic matter dynamics by degrading, retaining and releasing it (Hagopian and Riley, 1998; Rusten et al, 2006; Fernandes et al., 2017), which, ultimately, changes the $\mathrm{C} / \mathrm{N}$ ratio and the chemical composition and matrix of the water. Some studies have shown that the abundance of free-living bacteria in RAS rearing water is correlated to the abundance of bacteria attached to the biofilter media (Leonard et al., 2000; Michaud et al., 2006). It has also been demonstrated that the biofilter attenuates the immediate response of bacteria in the water phase when feed loading is increased (Rojas-Tirado et al., 2018). Likewise, it is a welldocumented that mature bacterial communities in biofilters can consume additional carbon sources fast (Davies, 2011; Pedersen et al., 2010) and, thereby, efficiently compete for the available carbon with bacteria suspended in the water. However, the dynamics between the biofilter and water column communities, and the variation in the RAS water CC due to increased supply of organic matter has, to our knowledge, not been studied so far.

The aim of the present study was to investigate the potential heterotrophic bacterial response in RAS water after pulse addition of easily degradable organic matter, simulating e.g. a pulse of organic matter in a tank or a system. Acetate, an easily biodegradable carbon source, was added to the water in two types of experiments: i) single addition of three acetate levels to RAS water in beakers; and ii) three consecutive days pulse addition of acetate to RAS in equilibrium, stocked with rainbow trout (Oncorhynchus mykiss), with or without submerged biofilter. Bacterial abundance and activity were assessed in the water phase with a set of quantitative monitoring tools that enumerated the density of single cells, microparticles, and evaluated the enzymatic activity of planktonic and particle-associated bacteria.

\section{Materials and Methods}

\subsection{System maturation and daily operation routines}

The experiments took place at the aquaculture facility of DTU Aqua in Hirtshals, Denmark. Twelve identical pilot scale freshwater RAS of $1.7 \mathrm{~m}^{3}$ each, were used for the trial. The systems configuration is described in Pedersen et al., (2012), with the modification that the volume of the submerged biofilter media was halved to match the feed load operated. Each system was stocked with $12.5 \mathrm{~kg}$ of rainbow trout and was fed a fixed amount of $125 \mathrm{~g}$ feed/day (EFICO Enviro $3 \mathrm{~mm}$, Biomar, Denmark). The daily water exchange for each RAS was $80 \mathrm{~L} /$ day, resulting in a feed loading of $1.56 \mathrm{~kg} / \mathrm{m}^{3}$. Every day at 9:00 a.m., solids were collected and removed from the system at the bottom of each swirl separator. Thereafter, make-up water was added; water quality parameters were measured, and bicarbonate was added to compensate for alkalinity loss due to nitrification. Finally, feed was added to belt feeders dosing the feed for a period of 6 hours. All systems where operated for five months (from December to April) to ensure stable microbiological and physiochemical conditions. No feed waste was observed during the operation of the systems.

\subsection{Experimental procedures}

This study was carried out in two separate experiments adding acetate to RAS water; one trial investigated the bacterial response in RAS water transferred to isolated beakers followed by a second trial where twelve independent and identical RAS under steady state conditions were used. The experiments were carried out to: i) quantify the effect of acetate addition in different quantities on bacterial abundance and activity in RAS 
water, and ii) evaluate the effect of a similar addition of easily biodegradable substrate to RAS with or without a submerged biofilter.

\subsubsection{Batch trial (experiment 1)}

To test the effect of easily biodegradable carbon on bacterial abundance and activity in RAS water, a beaker trial was carried out. Acetate was chosen as the easy biodegradable carbon source (Pedró-Alió and Brock, 1983; Canelhas et al., 2017), and was added in three different concentrations (Table 1): low concentration (LC) of $10 \mathrm{mg}$ acetate/L, medium concentration (MC) of $20 \mathrm{mg}$ acetate/L, a high concentration (HC) of $40 \mathrm{mg}$ acetate/L, compared to a control without addition of acetate. These acetate quantities represent a COD addition of $9.5,19$ and $38 \mathrm{mg} \mathrm{O}_{2} / \mathrm{L}$ simulating a theoretical daily feed increase by $1.6,3.2$ and 6.4 times, respectively, compared to a control group without acetate addition (Table 1).

Sixteen liters of water was taken from the pump sump in one of the 12 steady state RAS (randomly chosen), homogenized and distributed into eight $2 \mathrm{~L}$ beakers. The addition of acetate was done in duplicated beakers for each of the three different doses (Table 1). Two beakers were kept as the control group, and no acetate was added to them. All beakers were supplied with sufficient aeration and were stirred by a magnet at a velocity of 100 RPM to keep the water well mixed. The experiment was done at a fixed temperature of $17^{\circ} \mathrm{C}$, corresponding to the temperature of the RAS water. The experiments lasted for $72 \mathrm{~h}$, and samples were taken at regular intervals to assess acetate concentration and microbial water quality.

\subsubsection{Pilot scale RAS trial (experiment 2)}

To evaluate the effect of repeated addition of acetate in the presence or absence of a biofilter, twelve identical and independent RAS were used. In six of these RAS, the media in the submerged biofilter was removed 5 hours before the start of the experiment to let the system stabilize from any disturbances caused by removing the biofilter media. A trickling-filter with a $33 \mathrm{~m}^{2}$ active surface area remained in all systems mainly for degassing purposes. Four treatment groups were then established in triplicates: i) control RAS with a submerged biofilter (Ctrl+bf); ii) control RAS without a submerged biofilter (Ctrl-bf); iii) RAS spiked with acetate with a submerged biofilter (Ac+bf); and iv) RAS spiked with acetate without a submerged biofilter (Ac-bf). Each RAS from group (Ac+bf) and (Ac-bf) were spiked three consecutive times with the highest acetate concentration ( $40 \mathrm{mg}$ acetate/L): at time 0 , then a second time $24 \mathrm{~h}$ later, and a third time $48 \mathrm{~h}$ after the initial spike. The total study period was $72 \mathrm{~h}$. During the acetate spiking trials, RAS operation (i.e. feeding and water exchange) remained unchanged.

\subsection{Sampling and analysis procedures}

For experiment 2, the water samples were collected in a standardized way (same person, time, location) by siphoning gently from the pump sump of each RAS between 8:30-9:00 a.m. Water samples for experiment 1 and 2 were analyzed for bacterial activity and abundance. In addition, for experiment 2 ammonia, nitrite and nitrate were also measured to assess performance of the submerged biofilter in the RAS that had acetate added. Table 2 lists sampling procedures, treatment and processing of the microbial and physiochemical water quality analysis performed. For Experiment 1, water samples from each beaker were taken at time 0 , 6, 24, 48 and 72 hours. For Experiment 2, water samples from each RAS were taken at time 0, 2, 6, 12, 24, $30,48,54$ and 72 hours after the initial acetate spike. 
Bacterial activity in the water was assessed with two assays: BactiQuant ${ }^{\circledR}$ and the hydrogen peroxide (HP) degradation method. BactiQuant ${ }^{\circledR}$ was measured as described by Rojas-Tirado et al. (2017) and Pedersen et al. (2017), at time 0, 6, 24, 48 and 72 hours in Experiment 1, whereas for Experiment 2 samples were analyzed only at the beginning $(0 \mathrm{~h})$ and at the end $(72 \mathrm{~h})$. The hydrogen peroxide degradation assay is based on quantification of the microbial degradation of hydrogen peroxide as described by Arvin and Pedersen (2015) and Rojas-Tirado et al. (2018). Data for the HP removal rate in this study are presented as the HP degradation rate constant $\left(k, \mathrm{~h}^{-1}\right)$ calculated from the exponential decay equation: $C_{t}=C_{0}{ }^{*} e^{-k t}$, where $C_{t}=\mathrm{HP}$ concentration at time $\mathrm{t}$ and $C_{0}=$ the nominal HP concentration at time 0 .

The total number of suspended bacterial cells were quantified by flow cytometry (BD Accurim C6 Plus, Becton, Dickinson and Co., US) using Invitrogen ${ }^{\text {TM }}$ SYBR Green II (RNA gel stain in dimethyl sulfoxide, Thermo Fisher Scientific, US) as the fluorescent dye. Abundance of bacterial cells was determined by the gating on the fluorescence FL1 versus forward scatter (FSC) plot (BD Accuri ${ }^{\mathrm{TM}}$ C6 Software) shown in Fig.1. Bacterial numbers were divided into two groups: bacteria with high and bacteria with low relative RNA content. The RNA content in cells is highly correlated to growth-rate (Bremer and Dennis, 1987), and cells with high RNA content are considered to be actively growing. The water samples did not receive any treatment that could promote detachment of cell from particles. Therefore, the data are referred to as bacterial cells suspended in the water phase or "free-living bacteria". Free-living cells were counted in all 12 RAS. Microparticles ranging between 1 and $30 \mu \mathrm{m}$ in diameter were quantified with a Coulter counter (Multisizer 4e Coulter Counter, Beckman Coulter Life Science, US). This size range constitutes the dominant fraction of microparticles in RAS (Chen et al., 1993; Fernandes et al., 2015).

Acetate was measured by ion chromatography (Metrohm; Glostrup, DK). Total ammonia nitrogen (TAN), nitrite- $\mathrm{N}$, nitrate- $\mathrm{N}$, and phosphate (orthophosphate) were measured in each RAS at the beginning and at the end of experiment 2 (analytical methods procedures in Table 2).

\subsection{Data Analysis}

The data were processed and plotted using MS Excel and Prism Graph Pad 5.0. Data were normalized to time zero $\left(C / C_{0}\right)$ to facilitate comparisons of changes between the different variables. Effects of acetate concentrations on bacterial activity and micro-particle numbers were tested with a one-way analysis of variance (ANOVA). To evaluate differences in bacterial activity and abundance between the different treatments in Experiment 2, a one-way ANOVA was applied to the normalized data, using a probability level of 0.05 . For data not meeting the homoscedasticity assumption, one-way or two-way ANOVA on ranks (Kruskal-Wallis) were performed. Differences in treatment means were tested by Tukey's least square test. Statistics were performed using the software SigmaPlot 12.5 from Systat Software, Inc., San Jose California US.

\section{Results}

\subsection{Batch trial (Experiment 1)}

\subsubsection{Acetate degradation in RAS water}

The dissolved fraction of COD (COD ${ }_{\text {DISS }}$ ) in the tested RAS water before acetate addition was $35.6 \mathrm{mg} \mathrm{O}_{2} / \mathrm{L}$. After spiking with the three different acetate concentrations, the $\mathrm{COD}_{\text {DIss }}$ concentrations after $6 \mathrm{~h}$ were: 42.3 , 
51.0 and $73.8 \mathrm{mg} \mathrm{O}_{2} / \mathrm{L}$ for the low $(\mathrm{LC})$, medium (MC) and high ( $\mathrm{HC}$ ) acetate additions, respectively, compared to $35.0 \mathrm{mg} \mathrm{O} / 2 / \mathrm{L}$ in the control (Table 1 ). Acetate was degraded at a rate of $\sim 1 \mathrm{mg} / \mathrm{L}$ per hour in all treatments. The low and medium concentration $(10 \mathrm{mg} / \mathrm{L}$ and $20 \mathrm{mg} / \mathrm{L}$ ) was completely degraded within 24 hours, whereas the high concentration $(40 \mathrm{mg} / \mathrm{L})$ was completely degraded within 48 hours.

\subsubsection{Bacterial activity}

The rate constant $(\mathrm{k})$ of HP degradation increased $24 \mathrm{~h}$ after acetate addition, in a consistent manner with the organic load, reaching rates of $0.5,0.6,0.7$ and $0.8 \mathrm{~h}^{-1}$ for the control, LC, MC and HC groups, respectively (Fig. 2a; Table 3). Resulting with significant differences $(p<0.001)$ in bacterial activity at the end of the experiment for the different concentrations of acetate dosed.

BactiQuant ${ }^{\circledR}$ values ranged between 7 and $9 \times 10^{4} \mathrm{BQV} / \mathrm{ml}$ (Table 3 ) and no significant differences $(p>0.05)$ were found between treatments at the end of the experiment (Fig. 2b).

\subsubsection{Microparticles number and size distribution in RAS water}

Obvious difference in microparticle numbers where observed between two defined size class ranges ( 1 - 3 $\mu \mathrm{m}$ and $3-30 \mu \mathrm{m})$ after addition of acetate. Microparticles between 1 and $3 \mu \mathrm{m}$ increased according to acetate addition, whereas the microparticles from 3 to $30 \mu \mathrm{m}$ decreased in number with time in all treatments (Fig. $2 \mathrm{c}$ ). After $72 \mathrm{~h}$, the number of microparticles between $1-3 \mu \mathrm{m}$ ranged from 1.8 to $3.2 \times 10^{6}$ particles/ml for the LC to the HC (Fig. 2c; Table 3). The number of microparticles $1-3 \mu \mathrm{m}$ in untreated water (control) decreased linearly from 1.85 to $1.2 \times 10^{6}$ at the end of the experiment (Fig. 2c; Table 3). Microparticles in the size range from 1 to $3 \mu \mathrm{m}$ constituted $95 \%$ of the total number of particles within the total range from 1 to $30 \mu \mathrm{m}$. Significant differences $(p<0.001)$ were found in the concentration of microparticles ranging 1 to $3 \mu \mathrm{m}$ between treatments at the end of the experiment (Table 3 ).

After the acetate addition, particles increased in numbers but also in particle size (Fig. 3b, c). Figure 3a shows the changes in particle size distribution $(1-3 \mu \mathrm{m})$ for the different acetate additions $72 \mathrm{~h}$ after addition. In the control beakers, the most abundant particles were approximately $1 \mu \mathrm{m}$, whereas in the $\mathrm{LC}$ the most abundant particles were in the size range 1.0-1.2 $\mu \mathrm{m}$. In the $M C$, the most abundant particles were approximately $1.3 \mu \mathrm{m}$ in diameter, and for the $\mathrm{HC}$, the most abundant particles were approximately $1.8 \mu \mathrm{m}$ in diameter. Water samples from the HC treatment were observed under a microscope, revealing presence of diplococci and tetrad bacterial cell division (observations not quantified).

\subsection{Pilot scale RAS trial (Experiment 2)}

\subsubsection{Acetate degradation}

Acetate was rapidly degraded in the six RAS after each consecutive addition, and there was an adaptation to acetate consumption as acetate was consumed at a higher rate after each addition (Fig. 4a, 4b). All RAS with 
submerged biofilter (Ac+bf) removed $77 \pm 1.3 \%$ of the acetate after the first spike within the first 24 hours, compared to 64 - 99\% for the RAS without submerged biofilter (Ac-bf). Complete acetate degradation in all Ac+bf RAS, was observed $24 \mathrm{~h}$ after the second and third spike. An even faster consumption of acetate was observed in the RAS without submerged biofilter media (Ac-bf). After the second and the third spike, a 70 to $100 \%$ consumption of acetate was found after $6 \mathrm{~h}$ (Fig. 4). A high reproducibility between replicates was observed in treatment Ac+bf for acetate degradation. On the other hand, the replicates in treatment Ac-bf varied in acetate consumption after the first and second acetate spike and ended up with a more even degradation rate after the third spike.

\subsubsection{Bacterial activity}

Bacterial activity in the water, assessed with the BactiQuant ${ }^{\circledR}$ method, ranged five-fold from $3.4 \times 10^{4}$ to 1.76 $\times 10^{5} \mathrm{BQV} / \mathrm{ml}$ between the different RAS at the beginning of the experiment (Table 4 and 5 ). For the control group with or without submerged biofilter, most RAS had a small increase in BQV at the end of the experiment (Table 4). In the RAS where acetate was added, BQV decreased in all units with submerged biofilter (Ac+bf) compared to the start-up of the trial. The group without submerged biofilter (Ac-bf) ended with lower bacterial activity in two units (from 4.32 and $9.76 \times 10^{4} \mathrm{BQV} / \mathrm{ml}$ to 3.24 and $4.28 \times 10^{4} \mathrm{BQV} / \mathrm{ml}$ ) and a 10 times higher activity (from $6.54 \times 10^{4}$ to $6.76 \times 10^{5} \mathrm{BQV} / \mathrm{ml}$ ) in the third unit compared to the startup activity (Table 5). This relatively high activity caused significant differences in BQV between and within treatments $(p>0.05)$ at the end of the experiment.

The initial and final bacterial activities quantified with the HP degradation assay are shown in Table 4 and 5 for control and acetate groups, respectively. For both control groups (Ctrl+bf and Ctrl-bf) and the acetate group with submerged biofilter (Ac+bf), bacterial activity was relatively stable in most of the RAS during the three days of the trial (Fig. 5). The group without submerged biofilter which had acetate added (Ac-bf) differed significantly $(p<0.001)$ from the other three groups over the trial period. This group had, on average, 2.3 times higher bacterial activity than the control group $24 \mathrm{~h}$ after the first spike, and 4.6 and 5.4 higher activity after the second and third spikes, respectively (Fig. 5). At the end of the experiment, bacterial activity in two of the three RAS within group (Ac-bf) decreased to rates similar to those at the beginning of the experiment (Table 5).

\subsubsection{Bacterial abundance}

The initial and final bacterial cell concentrations for total, low and high RNA are presented in Table 4 and Table 5. The concentration of free-living bacteria decreased slightly in the water for both control groups (Ctrl+bf and Ctrl-bf) during the three days of the experiment (Fig. 6, Table 4). The RAS group Ac+bf had an increase of approximately 1.5 times more cells, $6 \mathrm{~h}$ after the third spike (Fig. 6 ). The RAS group Ac-bf showed an increase of 3.4 times in free-living bacteria right after the second spike. During that sampling, $28 \%$ of the total cells were high RNA cells, and this prevailed until the end of the experiment. After the third spike, bacteria in the RAS water declined in both acetate treatment Ac+bf and Ac-bf (Fig. 6). The absence of a submerged biofilter had a significant effect $(p<0.05)$ on the concentration of free-living bacteria in the water phase after a sudden increase in organic load. The Ac-bf treatment had $\sim 2.4$ times higher bacterial density than the Ac+bf treatment.

\subsubsection{Microparticles}


Particle concentration of two size classes are shown in Table 4 and Table 5. Particle concentration between 1-3 $\mu \mathrm{m}$ (microparticles 1 -3um) in the control RAS groups (Ctrl+bf and Ctrl-bf) remained relatively stable over the experimental period. A maximum increase of 1.5 times microparticles $1-3 \mu \mathrm{m}$ was observed within the control groups (Fig. 7, a; Table 4) and in the Ac+bf group the highest average increase was 1.8 times the initial particle concentration (Fig. 7). In the Ac-bf group, microparticles 1 -3um increased significantly $(p<0.05)$ compared to the other three treatment groups. A 10.8 time increase of particles was observed after the second and third spike. No differences between treatments were observed for microparticles within the size range $3-30 \mu \mathrm{m}$ (Fig. 7b).

\subsubsection{Concentration of inorganics $N$ and $P$}

The mean TAN concentration was $0.13 \pm 0.03 \mathrm{mg}$ TAN/L for the twelve RAS at the start of the trial. At the end of the experiment $(72 \mathrm{~h}$ ), the TAN concentration was $0.13 \pm 0.06 \mathrm{mg}$ TAN/L for the two control groups (Ctrl+bf and Ctrl-bf). The TAN concentration was the same for the Ac+bf treatment RAS ( $0.14 \pm 0.04 \mathrm{mg}$ TAN/L), but $\sim 2.7$ times higher in the acetate spiked RAS without submerged biofilter (Ac-bf) $(0.37 \pm 0.08 \mathrm{mg}$ TAN/L; $p<$ $0.05)$.

The mean nitrite- $\mathrm{N}$ concentration for the twelve RAS at the start of the trial was $0.05 \pm 0.01 \mathrm{mg} \mathrm{NO}-\mathrm{N} / \mathrm{L}$. Similarly as TAN, the concentrations were $0.08 \pm 0.05 \mathrm{mg} \mathrm{NO}_{2}-\mathrm{N} / \mathrm{L}$ for both Ctrl+bf and Ctrl-bf treatments at the end of the experiment, $0.05 \pm 0.02 \mathrm{mg} \mathrm{NO}-\mathrm{N} / \mathrm{L}$ for the Ac+bf RAS, and significantly higher $(p<0.05)$ at $0.19 \pm 0.03 \mathrm{mg} \mathrm{NO}-\mathrm{N} / \mathrm{L}$ in the Ac-bf treatment.

Nitrate concentrations were similar in all 4 treatment groups at the startup of the trail $(64.2 \pm 3 \mathrm{mg} \mathrm{NO}-\mathrm{N} / \mathrm{L})$. However, a significant reduction $(p<0.05)$ was observed in both treatment groups with acetate addition. At the end of the trial, the nitrate- $\mathrm{N}$ concentration in Ctrl+bf and Ctrl-bf was $61.8 \pm 1.7$ and $60.4 \pm 4.8 \mathrm{mg} \mathrm{NO}_{3}$ $\mathrm{N} / \mathrm{L}$, respectively, while in the Ac+bf and Ac-bf groups it was $53.5 \pm 7.0$ and $53.3 \pm 2.2 \mathrm{mg} \mathrm{NO}-\mathrm{N} / \mathrm{L}$.

Phosphate concentration before the start of the experiment were similar between the twelve RAS $(3.7 \pm 0.19$ $\mathrm{PO}_{4}-\mathrm{P} / \mathrm{L}$ ), ending at $3.6 \pm 0.04,3.7 \pm 0.1,3.0 \pm 0.5$ and $3.3 \pm 0.2 \mathrm{PO}_{4}-\mathrm{P} / \mathrm{L}$ for the Ctrl+bf, Ctrl-bf, Ac+bf and Ac$b f$, respectively, and without significant differences between treatments $(p>0.05)$. However, significant differences $(\mathrm{p}<0.05)$ were found when phosphate consumption was calculated $\left(\triangle \mathrm{PO}_{4}-\mathrm{P}=\mathrm{PO}_{4}-\mathrm{P}_{72 \mathrm{~h}}-\mathrm{PO}_{4^{-}}\right.$ $\left.\mathrm{Poh}_{\mathrm{oh}}\right)$ showing RAS spiked with acetate $\left(0.58 \pm 0.14\right.$ and $0.57 \pm 0.07 \mathrm{PO}_{4}-\mathrm{P} / \mathrm{L}$ for $\mathrm{Ac}+\mathrm{bf}$ and $\left.\mathrm{Ac}-\mathrm{bf}\right)$ to be significant higher than both control RAS $\left(0.06 \pm 0.02\right.$ and $0.08 \pm 0.06 \mathrm{PO}_{4}-\mathrm{P} / \mathrm{L}$ for Ctrl+bf and Ctrl-bf).

\section{Discussion}

\subsection{Dose-response effect of acetate addition to RAS water (Experiment 1)}

The addition of acetate had an immediate and prolonged additive effect on the bacterial dynamics in beakers with RAS water. This could be expected given the immediate bioavailability and nutritional characteristics of acetate (Pedrós-Alió and Brock, 1983; Canelhas et al., 2017), the inorganic nutrient content, and the bacterial load in RAS water (Rojas-Tirado et al., 2018). The unexposed RAS water had a linear reduction in bacterial activity (HP assay) of approximately $10 \%$ day as well as in particle numbers (1-3 $\mu \mathrm{m})$, with no changes in average size distribution over time (Fig $3 b$ ). Acetate addition caused a $50 \%$ increase in particle numbers (1$3 \mu \mathrm{m}$ ) within 24 hours, further increasing until 48 hours for the medium and high acetate concentrations. Since the 1-3 $\mu \mathrm{m}$ size-fraction includes single bacteria cells or low-number bacterial aggregates (due to cell 
division), the results verified that biodegradable carbon was the limiting factor for free-living bacteria growth in the RAS (Fig. 3a). In these beakers, temporal changes in particle size distribution and concentration within the 1-3 $\mu \mathrm{m}$ range were observed over time ( $72 \mathrm{~h}$, Fig $3 \mathrm{c}$ ), indicating an increase in bacterial size caused by cell aggregate formation presumably due to cell-division processes. This was confirmed by microscopic observations (authors pers. obs.). The numbers of larger microparticles (3-30 $\mu \mathrm{m})$ were reduced in all four treatment groups suggesting flocculation to bigger particles due to stirring and/or disintegration from degradation by particle associated bacterial activity (Pedersen et al., 2017).

BactiQuant ${ }^{\circledR}$ did not detect any changes in bacterial activity after acetate addition as the principle of the method relies on hydrolase enzyme (Reeslev et al., 2011). In the presence of acetate - which is a readily transportable and a low molecular weight compound (Chróst, 1991; Canelhas et al., 2017), bacteria do not require additional activation of hydrolase as acetate can be taken up by simple diffusion. Therefore, it is presumed that bacterial activity assessed by BactiQuant ${ }^{\circledR}$ remained constant even though different concentrations of added substrate resulted in changes in bacterial activity and cell numbers. A more realistic feed spill scenario would probably have caused formation of more complex bioavailable compounds, thereby activating bacterial hydrolases and hence, detectable changes in BactiQuant ${ }^{\circledR}$. A clear rise in BactiQuant ${ }^{\circledR}$ was thus observed when increasing e.g. feed loading in RAS (Rojas-Tirado et al., 2018). In contrast to BactiQuant ${ }^{\circledR}$, bacterial activity assessed by the HP degradation assay increased linearly according to the acetate concentrations given.

\subsection{Effects of repeated addition of acetate to pilot-scale RAS with or without biofilter (Experiment 2)}

Both RAS control groups (no acetate addition) reflected stability of the system in terms of microbial activity and abundance during the experimental period as no changes were observed. When acetate was repeatedly added at high concentrations to the RAS with submerged biofilter (Ac+bf), both bacterial activity and abundance in the water phase remained stable over time. This is somehow surprising, considering the fast and easy degradation of acetate in the systems with biofilter, the findings from experiment one, and the fact that bacteria were not inactivated by any disinfection treatments in the systems (Liltved and Cripps, 1999). This lack of change was considered to be related to the bacterial activity of the submerged biofilter. In RAS, bacterial communities will primarily reside in the biofilter due to the high surface area provided by the biofilter medium, the mutualism between different functional groups, and benefits of inhabiting surfaces which provide protection and keep bacteria from being flushed out (McDougald et al., 2011; Madigan et al., 2015), combined with the constant supply of nutrient-rich water. Consequently, the submerged biofilter functioned as a buffer by consuming the organic matter added and limiting the growth of bacteria in the water phase.

In this study, significant effects on microbial water quality parameters were only observed in the RAS where biomedia had been removed from the submerged biofilter (biofilter tank and trickling filter remaining; Acbf). In these RAS, increased bacterial activity and abundance in the water was measured by increased HP degradation rates and microparticles (1-3 $\mu \mathrm{m})$ abundance. Similar to the batch experiment (experiment 1$)$, the increase was significant after $24 \mathrm{~h}$, and bacterial activity remained elevated during the three consecutive acetate spikes. The flow cytometry data also showed an increase in free-living bacteria after addition of acetate. Approximately $30 \%$ of the bacteria had a high RNA content suggesting that this fraction was actively growing (Schaechter et al., 1958; Neidhardt et al., 1990). The three Ac-bf RAS displayed substantial intersystem variation, stressing that RAS, despite being identical in design and operation, are each unique as 
opposed to beaker trials. It is speculated, whether RAS-specific and localized micro hydraulics, and the absence of the submerged biofilter may explain part of this variation. Although no significant differences in microparticle ${ }_{3-30 \mu m}$ concentration was observed between the treatment groups, the graphs in Fig. $7 \mathrm{~b}$ shows higher particle numbers for all RAS without submerged biofilter (Ctrl-bf and Ac-bf). This indicates that the absence of the biofilter could have impacted the numbers of particles larger than $30 \mu \mathrm{m}$. Since no additional parameters were measured to assess the total organic matter content during experiment 2 this, however, remains an assumption.

During the experimental period (three days), TAN and nitrite did not increase much despite of the acetate addition. The small trickling filter most likely served as biofilter with nitrification during the trial period (Eding et al., 2006). Significant reduction of nitrate and phosphorus was measured within the RAS water spiked with acetate, which can be associated to cell growth (C:N:P ratio; Prest et al., 2016). Heterotrophic bacteria, present in the biofilm and in the water phase, can also assimilate ammonia when easily biodegradable carbon sources are added (Avnimelech, 1999; Hargreaves, 2006; Ebeling et al., 2006). This may lead to a reduced net - production of ammonia subsequently nitrite, concomitantly influencing the nitrate accumulation (or concentration). This was substantiated in the present study where a significant reduction in nitrate was found in the six acetate-treated RAS compared to the control RAS, although identical make-up water addition was applied in all twelve RAS.

\subsection{Analysis of results and microbial water quality methods}

Before the trial start-up, the RAS were operated under constant conditions and fixed feed loading for a prolonged period. During that time, bacteria stabilized according to the carrying capacity of the system, and carbon limited growth was established for the heterotrophic bacteria (Leonard et al., 2002; Attramadal et al., 2012; Rojas-Tirado et al., 2018). It can be hypothesized that the regular and constant substrate input (125 $\mathrm{g}$ feed/day for 5 months), was enough for bacteria in the water and the biofilter to uphold cellular maintenance only and, thus, reach a low but stable bacterial growth, regulated by cellular death (Gerardi, 2006). When acetate was added, the consumption rate of acetate increased after each spike, in line with the study by Canelhas et al. (2017). When exposed to a new source of substrate or increased concentrations of an already existing substrate, bacteria immediately adjust in the water phase and in the biofilm by increased activity and growth (Hagopian \& Riley, 1998; Pedersen et al., 2010; Davies, 2011; Blancheton et al., 2013, Rojas-Tirado et al., 2018). Higher availability of substrate allows heterotrophic bacteria in the biofilter, and especially bacteria in the water phase, to allocate metabolic energy to biomass production (growth), rather than cellular maintenance only (Canelhas et al., 2017). Moreover, this rapid change in the CC of the water probably allowed for growth of opportunistic r-strategist (fast growing bacteria) bacteria (Attramadal et al., 2016) as supported by the increase in the high RNA fraction observed. This 3.4 times increase in bacterial abundance in RAS water had, however, no immediate impact on the fish in this study (data not shown).

Interestingly, acetate consumption was faster in the RAS without submerged biofilter compared to those having a submerged biofilter, perhaps illustrating the adaptive features of bacteria living in the water phase, where they can live as free-living or attached to particles. This might be partly explained by the fact that the submerged biofilter would trap particles coming from e.g. fish feces, but since the biofilter media was removed, particles were instead distributed throughout the water column. This might have supported a fast and increased development of the microbial population in the water column (free-living and particle associated bacteria) in these RAS. Free-living bacteria might benefit from their larger surface to volume ratio 
providing more surface area for the absorption of substrates (Gerardi, 2006; Pedersen et al., 2017). Particleassociated bacteria have been observed to have a higher frequency of cell division and are generally larger than free-living bacteria which allows them a higher acetate uptake (Pedrós- Alió and Brock, 1983; Crespo et al., 2013). It can be assumed that these two adaptive aspects of the bacterial community in the water phase and the higher number of particles, combined with an easily degradable and abundant substrate, could have facilitated the faster acetate consumption observed in the RAS Ac-bf.

The monitoring tools used in this study detected changes in microbial water quality. However, each method had its own application. The Coulter counter instrument counts numbers of particles within the 1 to $30 \mu \mathrm{m}$ range, whereas bacterial size range is generally between 0.2 and $3 \mu \mathrm{m}$ (Gerardi, 2006). This means that single cells smaller than $1 \mu \mathrm{m}$ were not detected by the Coulter counter with the aperture used. Flow cytometry can differentiate between bacteria and inert particles using staining procedures (Marie et al., 2005) but it cannot quantify particles precisely in size groups as the Coulter counter although it managed measuring bacteria down to $1 \mu \mathrm{m}$. The microbial activity assays with HP showed strong positive correlation with acetate addition, whereas BactiQuant ${ }^{\circledR}$ documented stable hydrolysis activity as unaffected by acetate addition. The combination of all applied methods contributed to improve the understanding of bacterial dynamics in RAS in this case study. Additional information about community structure and shifts therein might provide additional information in future experiments.

Limited knowledge exists about the interactions between the bacterial communities living as biofilter/biofilm-resident on a solid carrier, or as free-living or particle-associated bacteria in the water phase. This biofilm-water interaction is system specific and the buffering capacity and stabilizing effect of biofilters deserves more attention. Future studies of biofilm growth dynamics in biofilters will improve the understanding of microbial interactions in RAS.

\section{Conclusions}

i) Addition of easily biodegradable dissolved carbon (acetate) in beakers with RAS water caused increased bacterial activity and abundance.

ii) Addition of acetate for three consecutive days to pilot-scale RAS with submerged biofilters did, however, not significantly affect the bacterial activity and abundance in the water phase. Only in RAS where the submerged biofilter media had been removed, was a significant response observed in the water phase. This confirms that the biofilm and surface-attached bacteria have the capacity to consume significant pulses of organic matter, thereby preventing the acute deterioration of the microbial water quality.

iii) The monitoring tools used in this study (flow cytometry, HP degradation assay, and particle Coulter counter) complementarily detected and described the abrupt changes in bacterial activity and abundance in the water due to pulse loading of organic matter.

\section{Acknowledgements}

Special thanks to technicians Ole M. Larsen and Rasmus F. Jensen for their help and assistance and to Ulla Sproegel and Brian Møller for all water analyses conducted at the Section for Aquaculture, DTU Aqua, 
Hirtshals. Thanks to MSc. Mia Tiller Mjøs from NTNU, Trondheim, Norway, for helping with the flow cytometry measurements and analysis. This project was sponsored by the COFASP ERA-NET partners, which has received funding from the European Union's Seventh Framework Programme for research, technological development and demonstration under grant agreement no. 321553.

\section{References}

Arvin, E., Pedersen, L-F. 2015. Hydrogen peroxide decomposition kinetics in aquaculture water. Aquacult. Eng. 64: $1-7$.

Attramadal, K.J.K, Salvesen, I., Xue, R., Øie, G., Størseth, T.R., Vadstein, O., Olsen, Y. 2012. Recirculation as a possible microbial control strategy in the production of marine larvae. Aquacult. Eng. 46: 27-39.

Attramadal, K. J. K., Minniti, G., Øie, G., Kjørsvik, E., Østensen, M.A., Bakke, I., Vadstein O. 2016. Microbial maturation of intake water at different carrying capacities affects microbial control in rearing tanks for marine fish larvae. Aquaculture 457: 68-72.

Avnimelech, Y. 1999. Carbon/nitrogen ratio as a control element in aquaculture systems. Aquaculture 176: $227-235$.

Bitton, G. 2011. Wastewater Microbiology. Fourth edition. Wiley-Blackwell, New Jersey, pp. 762.

Blancheton, J.P., Attramadal, K.J.K., Michaud, L., Roque d'Orbcastel, Vadstein, O. 2013. Insight into bacterial population in aquaculture systems and its implication. Aquacult. Eng. 53: 30-39.

Bremer, H., Dennis, P. P. 1987. Modulation of chemical composition and other parameters of the cell by growth rate. In: Neidhardt, F. C., Ingraham, J. L., Low, K. B., Magasanik, B., Schaechter, M., Umbarger, H. E., editors. Escherichia coli and Salmonella typhimurium: cellular and molecular biology. Vol. 2. Washington, D.C: American Society for Microbiology, pp.1527-1542.

Canelhas, M.R., Andersson, M., Eiler, A., Lindström, E.S., Bertilsson, S. 2017. Influence of pulsed and continuous substrate inputs on freshwater bacterial community composition and functioning in bioreactors. Env. Microbiol. 19 : 5078-5087. DOI: 10.1111/1462-2920.13979.

Chen, S., Timmons, M.B., Aneshansley, D.J., Bisogni, J.J. 1993. Suspended solids characteristics from recirculating aquaculture systems and design implications. Aquaculture 112: 143-155. 
Chróst, R.J. 1991. Environmental control of the synthesis and activity of aquatic microbial ectoenzymes. In : Chróst, R.J. (ed), Microbial enzymes in aquatic environments. Springer-Verlag, New York Inc., US, pp. $29-59$. DOI: 10.1007/978-1-4612-3090-8_3.

Crespo, B.G., Pommier, T., Fernández-Gómez, B., Pedrós-Alió, C. 2013. Taxonomic composition of the particle-attached and free-living bacterial assemblages in the Northwest Mediterranean Sea analyzed by pyrosequencing of the 16S rRNA. MicrobiologyOpen 2 (4): 541-552.

Dalsgaard, J., Pedersen, P.B. 2011. Solid and suspended/dissolved waste (N,O,P) from rainbow trout (Oncorynchus mykiss). Aquaculture 313: 92-99.

Davies, D. 2011. Biofilm Dispersion. In: Flemming, H-C, Wingender, J., Szewzyk, U. (eds), Biofilm highlights. Springer Series on Biofilms 5. Springer-Verlag, Berlin, pp. 243. DOI: 10.1007/978-3-642-19940-0_1.

DS 223. 1991. Water analysis - Determination of the sum of nitrite- and nitrate-nitrogen. Danish Standards Foundation, Charlottenlund, Denmark.

DS 224. 1975. Water Analysis - Determination of Ammonia-Nitrogen. Danish Standards Foundation, Charlottenlund, Denmark.

Ebeling, J.M., Timmons, M.B., Bisogni, J.J. 2006. Engineering analysis of the stoichiometry of photoautotrophic, autotrophic, and heterotrophic removal of ammonia-nitrogen in aquaculture systems. Aquaculture 257: 346-358.

Fdz-Polanco, F., Méndez, E., Urueña, M.A., Villaverde, S., García, P.A. 2000. Spatial distribution of heterotrophs and nitrifiers in a submerged biofilter for nitrification. Water Res. 34 (16): $4081-4089$.

Fernandes, P. 2015. Interactions between micro-particles and the rearing environment in recirculating aquaculture systems. Ph.D thesis. Section for Aquaculture, DTU Aqua, Technical University of Denmark, Hirthals, Denmark, pp. 122.

Fernandes, P.M., Pedersen, L-F., Pedersen, P.B. 2015. Microscreen effects on water quality in replicated recirculating aquaculture systems. Aquacult. Eng. 65: 17-26.

Fernandes, P.M., Pedersen, L-F., Pedersen, P.B. 2017. Influence of fixed and moving bed biofilters on micro particle dynamics in a recirculating aquaculture system. Aquacult. Eng. 78: 32-41.

Gerardi, M. 2006. Wastewater Bacteria. John Wiley \& Sons, Inc., New Jersey, pp. 251.

Gonzalez-Silva, B.M., Jonassen, K.R., Bakke, I., Østgaard, K., Vadstein, O. 2016. Nitrification at different salinities: Biofilm community composition and physiological plasticity. Water Res. 95: 48 - 58.

Hagopian, D.S., Riley, J.G. 1998. A closer look at the bacteriology of nitrification. Aquacult. Eng. 18: 223-244.

Hargreaves, J.A. 2006. Photosynthetic suspended-growth systems in aquaculture. Aquacult. Eng. 34: $344-$ 363.

ISO 6878:2004. 2004. Water quality - determination of phosphorus - ammonium molybdate spectrometric method. International Organization for Standardization, Geneva, Switzerland, pp. 21. 
Leonard, N., Blancheton, J.P., Guiraud, J.P. 2000. Populations of heterotrophic bacteria in an experimental recirculating aquaculture system. Aquacult. Eng. 22: 109 - 120.

Leonard, N., Guiraud, J.P., Gasset, E., Cailleres, J.P., Blancheton, J.P. 2002. Bacteria and nutrients - nitrogen and carbon - in a recirculating system for sea bass production. Aquacult. Eng. 26: 111-127.

Liltved, H., Cripps, S.J. 1999. Removal of particles-associated bacteria by prefiltration and ultraviolet irradiation. Aquac. Res. 30: 445-450.

Madigan, M.T., Martinko, J.M., Bender, K.S., Buckley, D.H., Stahl, D.A., Brock, T. 2015. Brock biology of microorganisms. 14 ${ }^{\text {th }}$ edition, Glenview, IL: Pearson Education, pp. 1105.

Marie, D., Simon, N., Vaulot, D. 2005. Phytoplankton cell counting by flow cytometry. In: Andersen, R. (Ed.), Algal Culturing Techniques. Elsevier Academic Press, Oxford, UK: 253-285.

McDougald, D., Rice, S.A., Barraud, N., Steinberg, P.D., Kjelleberg, S. 2011. Should we stay or should we go: mechanisms and ecological consequences for biofilm dispersal. Nat. Rev. Microbiol. 10: 39-50.

Michaud, L., Blancheton, J.P., Bruni, V., Piedrahita, R. 2006. Effect of particulate organic carbon on heterotrophic bacterial populations and nitrification efficiency in biological filters. Aquacult. Eng. 34: 224233.

Michaud, L., Lo Giudice, A., Troussellier, M., Smedile, F., Bruni, V., Blancheton, J.P. 2009. Phylogenetic characterization of the heterotrophic bacterial communities inhabiting a marine recirculating aquaculture system. J. App. Microbiol. 107: 1935 - 1946.

Michaud, L., Lo Giudice, A., Interdonato, F., Triplet, S., Ying, L., Blancheton, J.P. 2014. C/N ratio-induced structural shift of bacterial communities inside lab-scale aquaculture biofilters. Aquacult. Eng. 58: $77-87$.

Neidhardt, F.C., Ingraham, J.L., Schaechter, M. 1990. Physiology of the bacterial cell: a molecular approach. Sinauer Associates, Inc. Sunderland, Massachussetts. pp. 507.

Nogueira, R., Melo, L.F., Purkhold, U., Wuertz, S., Wagner, M. 2002. Nitrifying and heterotrophic population dynamics in biofilm reactors: effects of hydraulic retention time and the presence of organic carbon. Water Res. 36: $469-481$.

Pedersen, L-F., Pedersen, P.B., Nielsen, J.L., Nielsen, P.H. 2010. Long term/low dose formalin exposure to small-scale recirculation aquaculture systems. Aquacult. Eng. 42: 1-7.

Pedersen, L-F., Suhr, K., Dalsgaard, J., Pedersen, P., Arvin, E. 2012. Effect of feed loading on nitrogen balances and fish performance in replicated recirculating aquaculture systems. Aquaculture 338-341: $237-245$.

Pedersen, P.B., von Ahnen, M., Fernandes, P., Naas, C.; Pedersen, L-F., Dalsgaard, J. 2017. Particle surface area and bacterial activity in recirculating aquaculture systems. Aquacult. Eng. 78: 18-23.

Pedró-Alió, C. Brock, T.D. 1983. The importance of attachment to particles for planktonic bacteria. Arch. Hydrobiol. 98 (3): $354-379$.

Prest, E.I., Hammes, F., van Loosdrecht, M.C.M., Vrouwenvelder, J.S. 2016. Biological stability of drinking water: Controlling factors, methods and challenges. Front. Microbiol. 7: 45. DOI: 10.3389/fmicb.2016.00045. 
Reeslev, M., Nielsen, J., Rogers, L. 2011. Assessment of the bacterial contamination and remediation efficacy after flooding using fluorometric detection. J. ASTM Int. 8 (10): 1-5.

Rojas-Tirado, P., Pedersen, P.B., Pedersen, L-F. 2017. Bacterial activity dynamics in the water phase during start-up of recirculating aquaculture systems. Aquacult. Eng. 78: 24-31.

Rojas-Tirado, P., Pedersen, P.B., Vadstein, O., Pedersen, L-F. 2018. Changes in microbial water quality in RAS following altered feed loading. Aquacult. Eng. 81: 80-88.

Rud, I., Kolarevic, J., Holan, A., Berget, I., Calabrese, S., Terjesen, B. 2017. Deep-sequencing of the bacterial microbiota in commercial-scale recirculating and semi-closed aquaculture systems for Atlantic salmon postsmolt production. Aquacult. Eng. 78: 50-62.

Rusten, B., Eikebrokk, B., Ulgenes, Y., Lyngren, E. 2006. Design and operations of the Kaldnes moving bed biofilm reactors. Aquacult. Eng. 34: 322-331.

Schaechter, E., Maaloe, O., Kjeldgaard, N.O. 1958. Dependency on medium and temperature of cell size and chemical composition during balanced growth of Salmonella typhimurium. J. Gen. Microbiol. 19: 592-606.

Vadstein, O., Øie, G., Olsen, Y., Salvesen, I., Skjermo, J., Skjåk-Bræk, G. 1993. A strategy to obtain microbial control during larval development of marine fish. In: Reinertsen, H., Dahle, L.A., Jørgensen, L., Tvinnereim, K. (eds). Fish Farming Technology - Proceedings of the First International Conference on Fish Farming Technology Balkema: Rotterdam, pp. 69-75.

van der Kooij, D., Visser, A., Hijnen, W.A.M. 1982. Determining the concentration of easily assimilable organic carbon in drinking water. J. Am. Water Works Assoc. 74: 540-545.

Wold, P., Holan, A., Øie, G., Attramadal, K., Bakke, I., Vadstein, O., Leiknes, T. 2014. Effects of membrane filtration on bacterial number and microbial diversity in marine recirculating aquaculture system (RAS) for Atlantic cod (Gadus morhua L.) production. Aquaculture 422 - 423: 69- 77.

Zhu, S., Chen, S. 2001. Effects of organic carbon on nitrification rate in fixed film biofilters. Aquacult. Eng. 25: $1-11$.

\section{FIGURES AND TABLES}

(Figure for Mat\&Meth) 


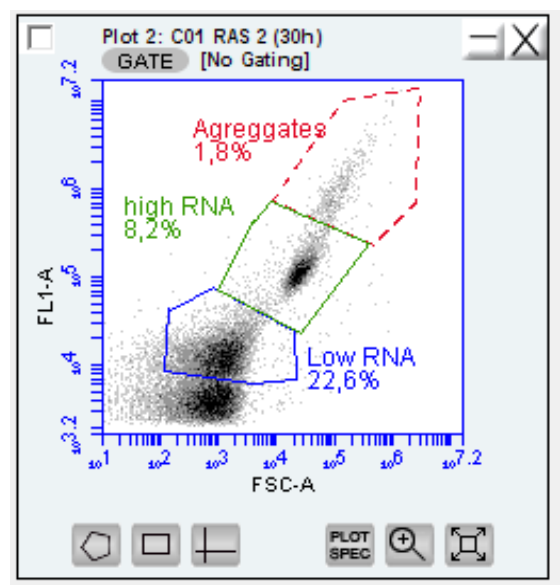

Fig. 1: Gating of cells counted with flow cytometry method. Cell gating was used to divide bacteria into two groups, low RNA and high RNA, separating them from the aggregates. Only low and high RNA groups are taken into consideration in the cell counting. The same gating was applied for all water samples. Bacterial cells were stained with SYBR green II. Cells were delimited by gating using BD Accuri ${ }^{\mathrm{TM}}$ C6 Software (figure from this study).

\section{(Results figures)}



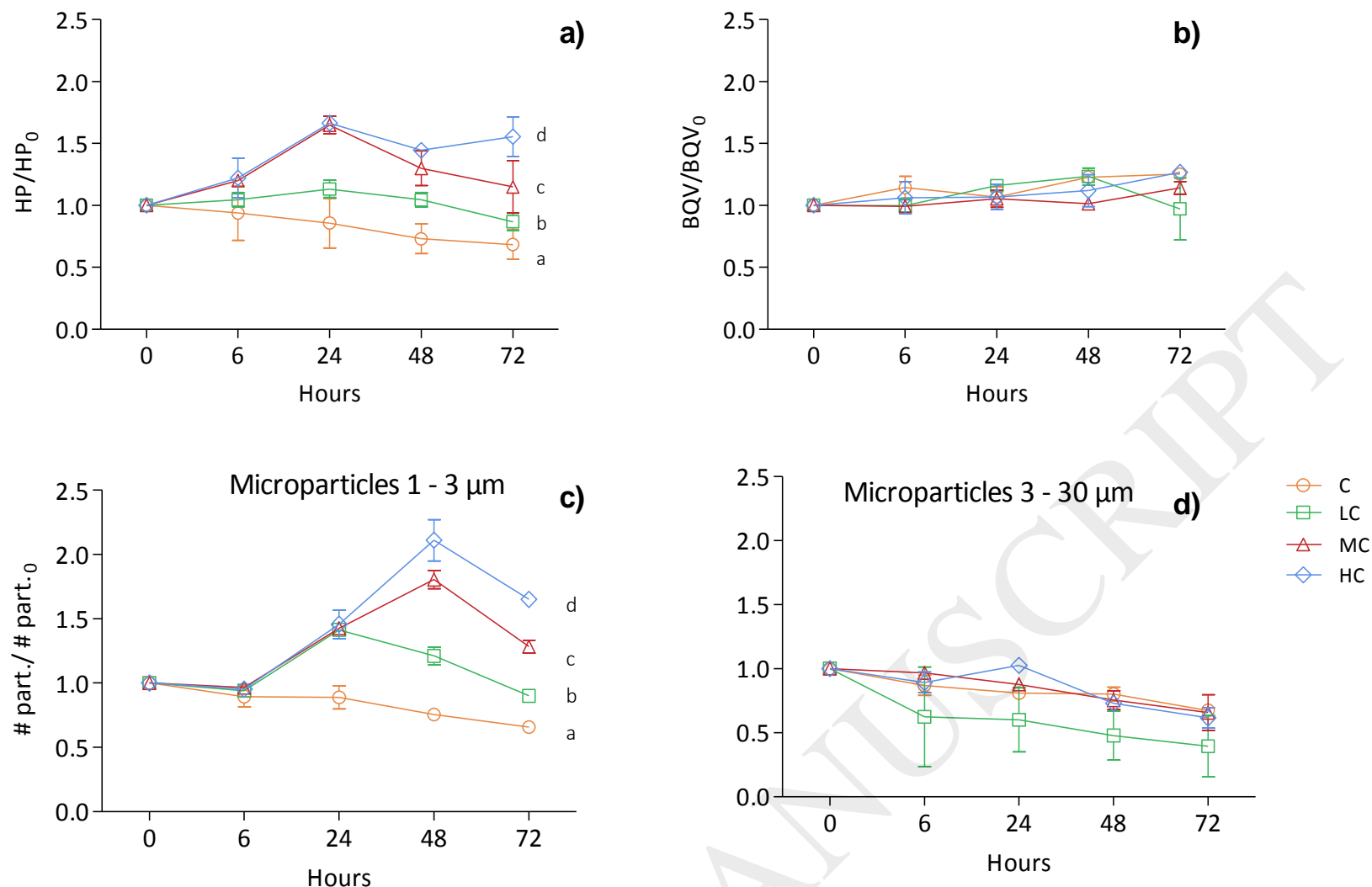

Fig. 2: Effect of acetate spike on (C: control; LC: low concentration; MC, medium concentration; HC: high concentration): a) hydrogen peroxide removal rate, b) bactiquant value (BQV), and c) number of particles within the range 1 - $3 \mu \mathrm{m}$; and d) number of particles within the range 3 - $30 \mu \mathrm{m}$. Data are normalized to time zero $\left(C / C_{0}\right)$ and presented as mean $\pm S D, n=2$ (raw data for 0 and $72 \mathrm{~h}$ presented in Table 3). Different superscripts within each separate figure indicate statistical difference between treatments $(p \leq 0.05)$. 

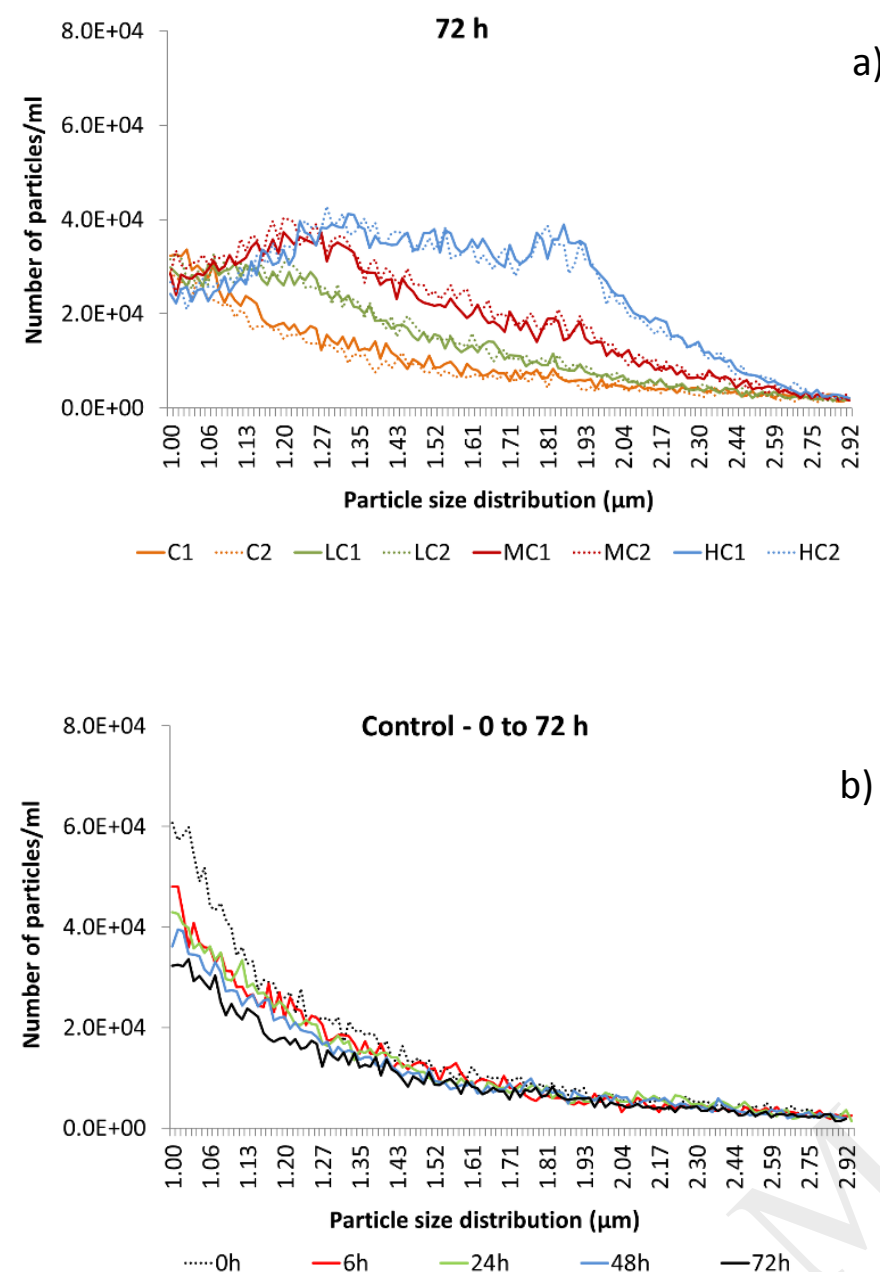

b)

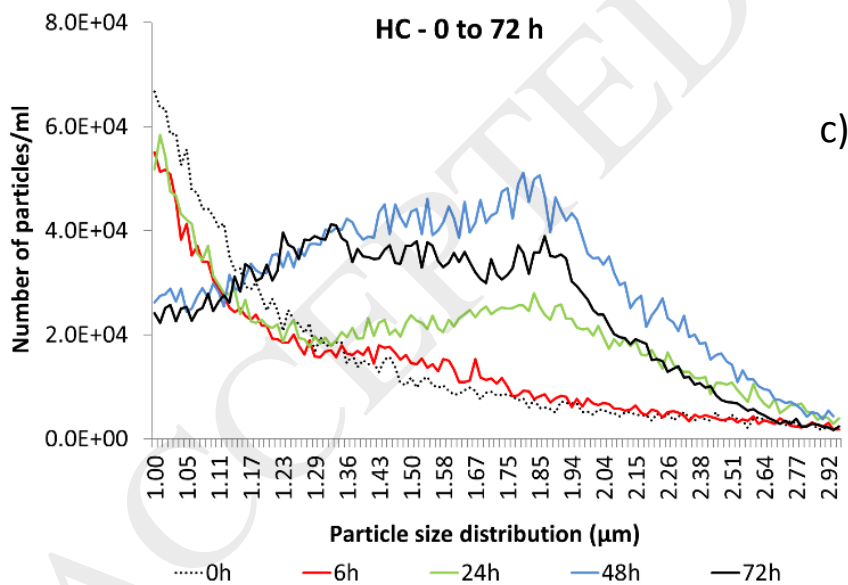

Fig. 3: Particle numbers and development within the size distribution 1 - $3 \mu \mathrm{m}$ following acetate addition to RAS water in beakers during Experiment 1: a) Changes in size distribution $72 \mathrm{~h}$ after different acetate addition (C1-2: no addition, LC1-2: $10 \mathrm{mg} / \mathrm{L}$ added, MC1-2: $20 \mathrm{mg} / \mathrm{L}$ added, HC1-2: $40 \mathrm{mg} / \mathrm{L}$ added); b) development in particle numbers and size in one of the control beakers (C1) through $72 \mathrm{~h}$; and c) development in particle numbers and size distribution in one of the beakers with high acetate concentration $(40 \mathrm{mg} / \mathrm{L})$ added. 


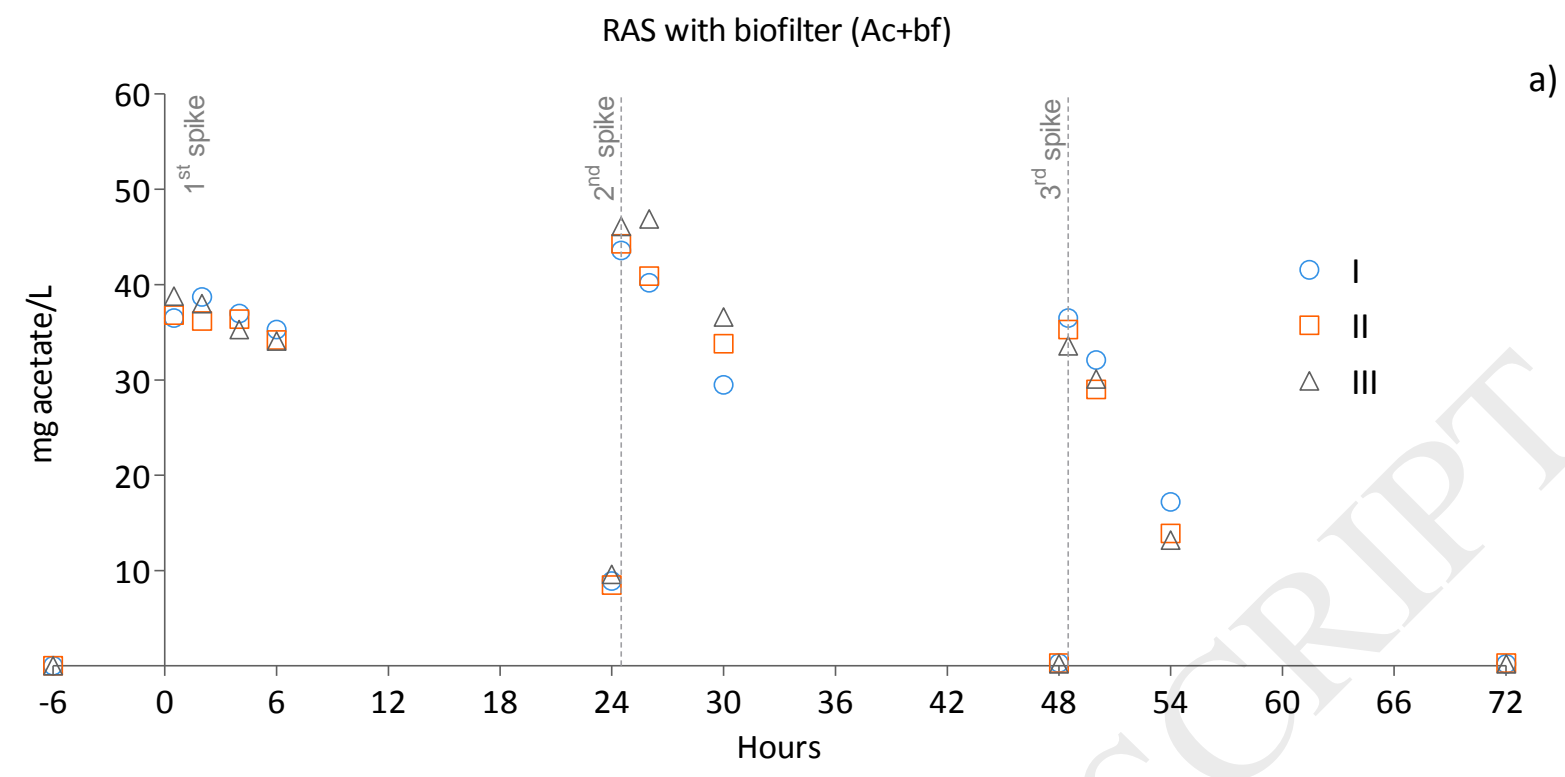

RAS without biofilter (Ac-bf)

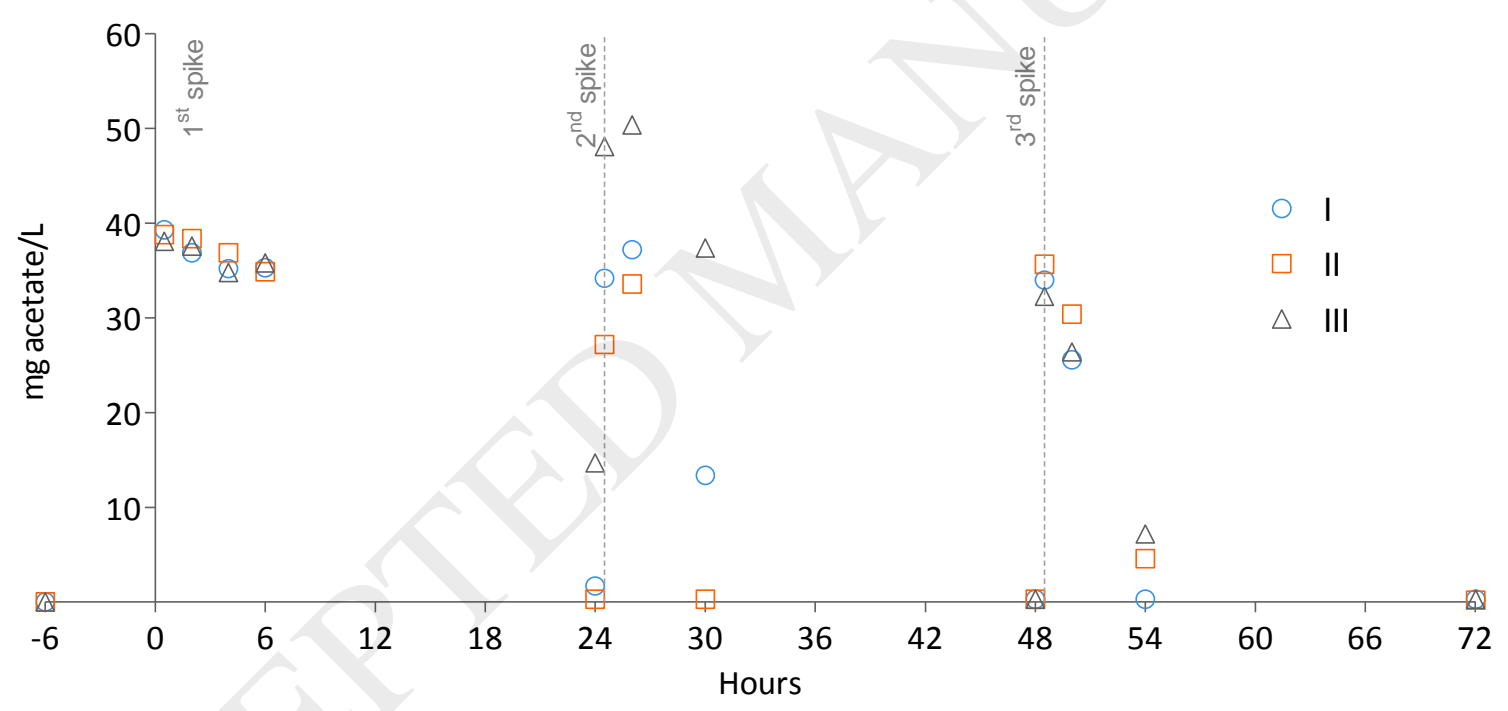

b)

Fig 4: Acetate concentrations in RAS following acetate spikes at $t=0,24$ and 48 h during Experiment 2, in: a) RAS with submerged biofilter (Ac+bf) and b) RAS without submerged biofilter (Ac-bf). Roman numerals in legend indicate RAS replicates for each treatment. 


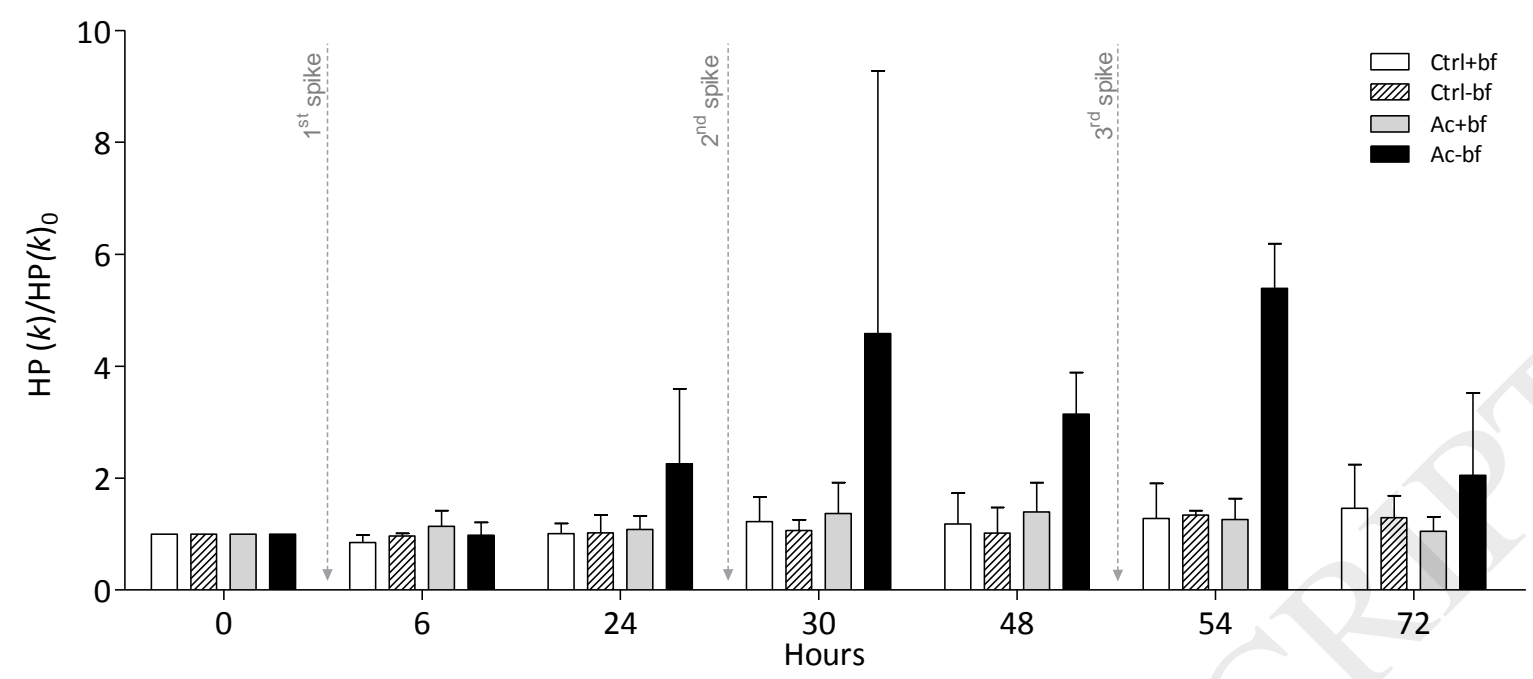

Fig. 5: Changes in bacterial activity expressed by changes in the hydrogen peroxide (HP) removal rate constant $k$ ( $h^{-1}$ ) for the different treatment groups during $72 \mathrm{~h}$ in Experiment 2: control RAS with submerged biofilter (Ctrl+bf) (white bars), control RAS without submerged biofilter (Ctrl-bf) (stripe bars), RAS with submerged biofilter (Ac+bf) spiked with acetate at $t=0,24,48 \mathrm{~h}$ (grey bars), and RAS without submerged biofilter (Ac-bf) spiked with acetate at $t=0$, 24, $48 \mathrm{~h}$ (black bars). Data are normalized $\left(C / C_{0}\right)$ and presented as mean $\pm S D, n=3$ (raw data for 0 and $72 \mathrm{~h}$ are presented in Table 4 and 5). 


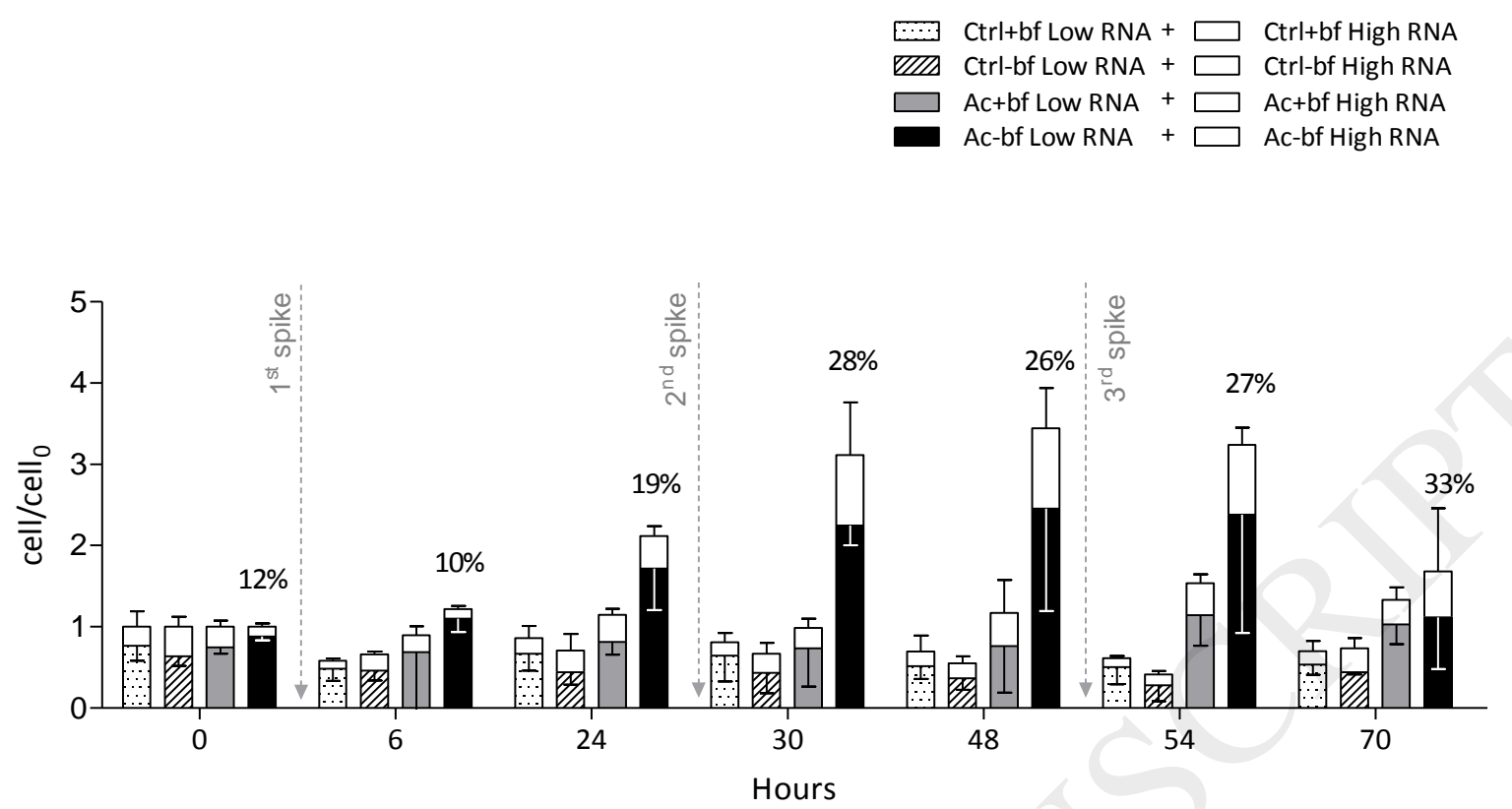

Fig. 6: Changes in bacterial abundance for the different treatment groups during $72 \mathrm{~h}$ in Experiment 2. For the low RNA cell counting: control RAS with submerged biofilter (Ctrl+bf) (white bars), control RAS without submerged biofilter (Ctrl-bf) (stripe bars), RAS with submerged biofilter (Ac+bf) spiked with acetate at $t=0,24,48 \mathrm{~h}$ (grey bars), and RAS without submerged biofilter (Ac-bf) spiked with acetate at $t=0,24,48 \mathrm{~h}$ (black bars). High RNA cells counting are shown as white upper bars and the percentage (\%) corresponding to the high RNA fraction of the total cell count is presented only for the Ac-bf group. Data are normalized $\left(C / C_{0}\right)$ and presented as mean $\pm S D, n=3$ (raw data for 0 and $72 \mathrm{~h}$ are presented in Table 4 and 5 ). 


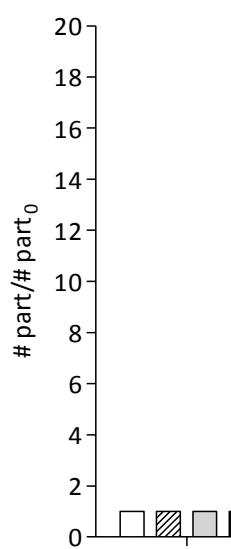

0

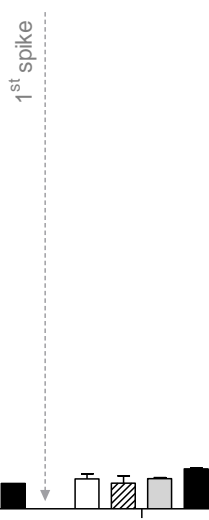

6

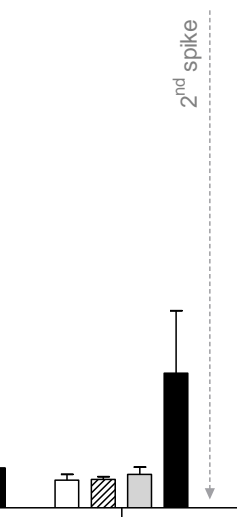

24

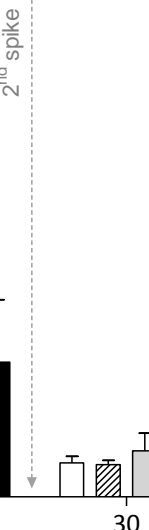

Hours

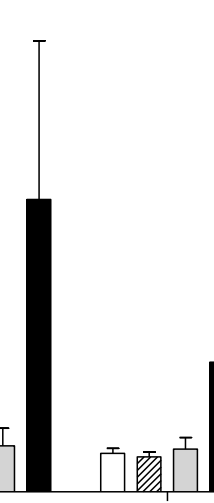

48

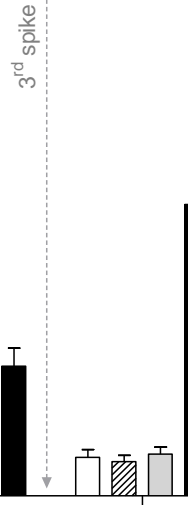

54

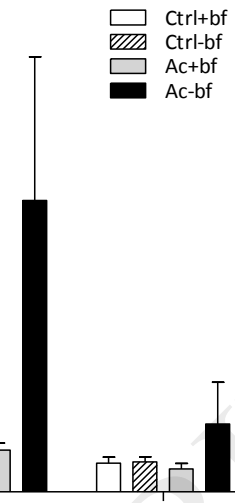

72

Microparticles 3-30 $\mu \mathrm{m}$

b)

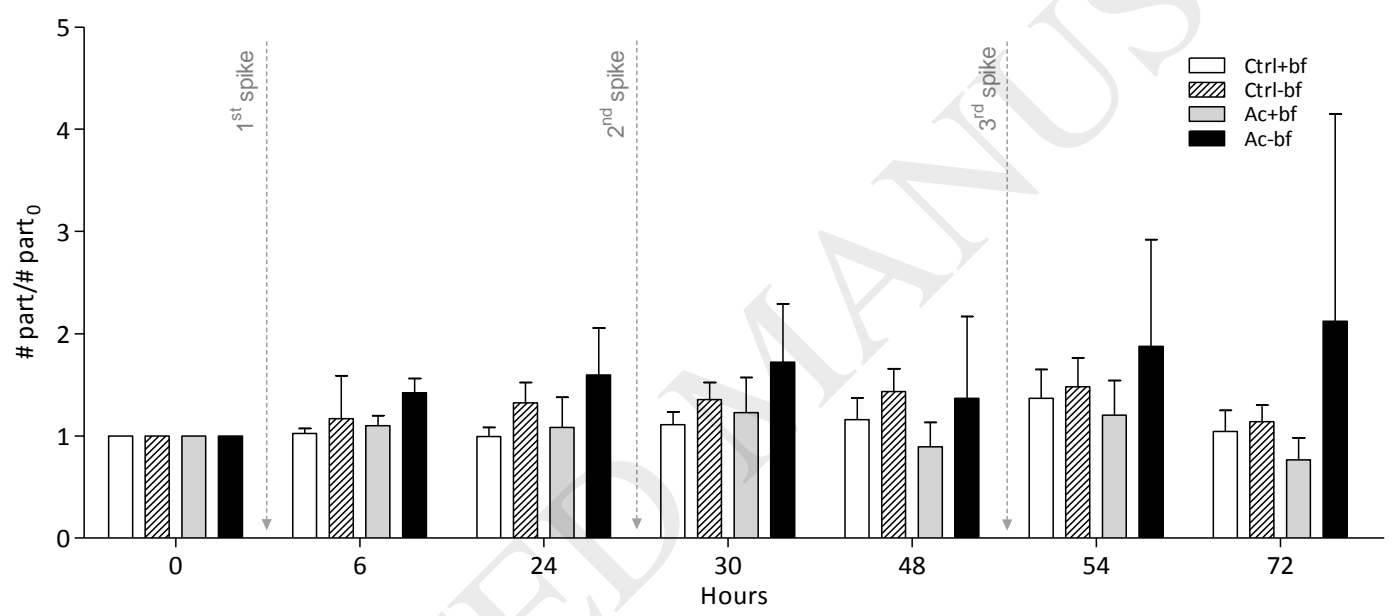

Fig 7: Number of microparticles $1-3 \mu \mathrm{m}$ (a) and 3 - $30 \mu \mathrm{m}$ (b) for the different treatment groups during $72 \mathrm{~h}$ in Experiment 2: control RAS with submerged biofilter (Ctrl+bf) (white bars), control RAS without submerged biofilter

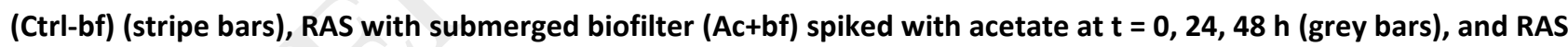
without submerged biofilter (Ac-bf) spiked with acetate at $t=0,24,48 \mathrm{~h}$ (black bars). Data are normalized (C/ $\left.\mathrm{C}_{0}\right)$ and presented as mean \pm SD, $n=3$ (raw data for 0 and $72 \mathrm{~h}$ are presented in Table 4 and 5). 
Table 1: Acetate concentrations (LC: low concentration, MC: medium concentration, HC: high concentration) used in experiment 1 and 2, and the corresponding chemical oxygen demands (COD) and theoretical equivalents of feed addition.

\begin{tabular}{|c|c|c|c|c|c|}
\hline Parameters & Units & Daily feeding & LC & MC & $\mathrm{HC}$ \\
\hline Acetate & $\mathrm{mg} / \mathrm{L}$ & - & 10 & 20 & 40 \\
\hline Theoretical COD & $\mathrm{mg} \mathrm{O}_{2} / \mathrm{L}$ & $6^{\mathrm{a}}$ & 9.5 & 19 & 38 \\
\hline Feed (g/day) & $\mathrm{g}$ & 125 & 125 & 125 & 125 \\
\hline Theoretical feed equivalents ${ }^{\mathrm{b}}$ (g/spike) & & 0 & 198 & 399 & 798 \\
\hline
\end{tabular}

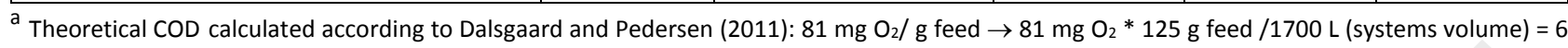
$\mathrm{mg} \mathrm{O} / \mathrm{L} ;{ }^{\mathrm{b}}$ Additional feed equivalent for $\mathrm{LC}, \mathrm{MC}$ and $\mathrm{HC}$ treatments based on the theoretical COD of $125 \mathrm{~g}$ feed and COD in the spiked acetate quantities.

Table 2: Microbial and physio-chemical water quality parameters and analytical methods used.

\begin{tabular}{|c|c|c|c|c|c|}
\hline Parameter & $\begin{array}{l}\text { Abbreviation } \\
\text { /Description }\end{array}$ & Units & Sample treatment and processing & Analytical Method/Instrumentation & Reference \\
\hline Bacterial Activity & BactiQuant Value & BQV & Unfiltered. Processed immediately & BactiQuant ${ }^{\circledast}$ (Mycometer, Denmark) & $\begin{array}{l}\text { Manufacturers } \\
\text { protocol }\end{array}$ \\
\hline Bacterial Activity & $\begin{array}{l}\text { HP degradation } \\
\text { Assay }\end{array}$ & $k\left(h^{-1}\right)$ & Unfiltered. Processed immediately & Colorimetry & $\begin{array}{l}\text { Arvin and Pedersen, } \\
2015\end{array}$ \\
\hline Bacteria cell number & Cell number & cell/ $\mu \mathrm{l}$ & $\begin{array}{l}\text { Unfiltered. Fixed with glutaric aldehyde } \\
(1 \% \text { final concentration). Frozen } \\
\text { immediately with liquid nitrogen gas and } \\
\text { conserved at }-20^{\circ} \mathrm{C} \text {. Processed } 6 \text { months } \\
\text { later. }\end{array}$ & $\begin{array}{l}\text { Stained with Sybr Green II and counted } \\
\text { with Flow Cytometer (Becton Dickinson } \\
\text { FACscan) }\end{array}$ & $\begin{array}{l}\text { (Marie et al., 2005; } \\
\text { Wold et al., 2014) }\end{array}$ \\
\hline Particle numbers & & & $\begin{array}{l}\text { Prefiltered with a } 45 \mu \mathrm{m} \text { AA filter. Counted } \\
\text { immediately }\end{array}$ & Multisizer 4e Coulter Counter & N/A \\
\hline $\begin{array}{l}\text { Temperature, } \quad \mathrm{pH}, \\
\text { Dissolved Oxygen }\end{array}$ & Temp., pH, $\mathrm{O} 2$ & $\begin{array}{ll}{ }^{\circ} \mathrm{C}, \mathrm{pH} \\
\text { units, } \mathrm{mg} / \mathrm{L}\end{array}$ & N/A & $\begin{array}{l}\text { Hach HQ40d Instruments, Hach Lange, } \\
\text { Germany }\end{array}$ & N/A \\
\hline Acetate & & $\mathrm{mg} / \mathrm{L}$ & Filtered $0.22 \mu \mathrm{m}$. Conserved at $4^{\circ} \mathrm{C}$. & $\begin{array}{l}\text { Ion chromatography, Metrohm, Glostrup - } \\
\text { DK }\end{array}$ & N/A \\
\hline \begin{tabular}{ll|}
$\begin{array}{l}\text { Total ammonia } \\
\text { nitrogen }\end{array}$ & \\
\end{tabular} & TAN & $\mathrm{mg} / \mathrm{L}$ & Filtered $0.22 \mu \mathrm{m}$. Conserved at $4^{\circ} \mathrm{C}$. & Colorimetry & DS 224 \\
\hline Nitrite & $\mathrm{NO}_{2}-\mathrm{N}$ & $\mathrm{mg} / \mathrm{L}$ & Filtered $0.22 \mu \mathrm{m}$. Conserved at $4^{\circ} \mathrm{C}$. & Colorimetry & DS 223 \\
\hline Nitrate & $\mathrm{NO}_{3}-\mathrm{N}$ & $\mathrm{mg} / \mathrm{L}$ & Filtered $0.22 \mu \mathrm{m}$. Conserved at $4^{\circ} \mathrm{C}$. & Colorimetry & DS 223 \\
\hline $\begin{array}{l}\text { Phosphate } \\
\text { (orthophosphate) }\end{array}$ & $\mathrm{PO}_{4}-\mathrm{P}$ & $\mathrm{mg} / \mathrm{L}$ & Filtered $0.22 \mu \mathrm{m}$. Conserved at $4^{\circ} \mathrm{C}$. & Colorimetry & ISO 6878:2004 \\
\hline $\begin{array}{l}\text { Dissolved chemical } \\
\text { oxygen demand }\end{array}$ & $\mathrm{COD}_{\mathrm{DISS}}$ & $\mathrm{mg} \mathrm{O}_{2} / \mathrm{L}$ & Filtered $0.22 \mu \mathrm{m}$. Conserved at $4^{\circ} \mathrm{C}$. & LCK 914, Hach Lange, Germany & N/A \\
\hline
\end{tabular}

Table 3: Results from experiment 1 (beaker trial) for the microbial water quality parameters (mean $\pm S D, n=3$ ) in control (C), low concentration (LC), medium concentration (MC) and high acetate concentration (HC) from Experiment 1.

\begin{tabular}{|c|c|c|c|c|c|c|}
\hline Parameter & Unit & Time & C & LC & MC & $\mathrm{HC}$ \\
\hline \multirow{2}{*}{ BactiQuant } & \multirow{2}{*}{$\mathrm{BQV} \times 10^{4} / \mathrm{ml}$} & $\mathrm{Oh}$ & $6.8-7$ & 7.1 & $7.1-7.6$ & 6.9 \\
\hline & & $72 \mathrm{~h}$ & $8.3-9$ & $5.7-8.1$ & $7.9-9.0$ & $8.6-8.9$ \\
\hline & 11 & & & & & \\
\hline \multirow{2}{*}{$\mathrm{HP}$} & \multirow{2}{*}{$h^{-1}$} & $\mathrm{Oh}$ & $0.75 \pm 0.13$ & $0.69 \pm 0.04$ & $0.60 \pm 0.00$ & $0.54 \pm 0.00$ \\
\hline & & $72 \mathrm{~h}$ & $0.51 \pm 0.04$ & $0.60 \pm 0.08$ & $0.69 \pm 0.13$ & $0.84 \pm 0.08$ \\
\hline \multirow{2}{*}{$\begin{array}{c}\text { Microparticles } \\
1-3 \mu \mathrm{m} \\
\end{array}$} & \multirow{2}{*}{ \#part $\times 10^{6} / \mathrm{ml}$} & $\mathrm{Oh}$ & $1.8-1.9$ & $1.7-1.9$ & $1.8-1.9$ & $1.8-1.9$ \\
\hline & & $72 \mathrm{~h}$ & $1.1-1.3$ & $1.7-1.8$ & $2.3-2.5$ & 3.2 \\
\hline \multirow{2}{*}{$\begin{array}{c}\text { Microparticles } \\
3-30 \mu \mathrm{m}\end{array}$} & \multirow[b]{2}{*}{ \#part $\times 10^{5} / \mathrm{ml}$} & $\mathrm{Oh}$ & $1.2-1.3$ & $1.2-2.3$ & 1.2 & 1.2 \\
\hline & & $72 \mathrm{~h}$ & 0.8 & $0.6-0.7$ & $0.8-0.9$ & $0.6-0.8$ \\
\hline
\end{tabular}


Table 4: Microbial water quality parameters for RAS without acetate.

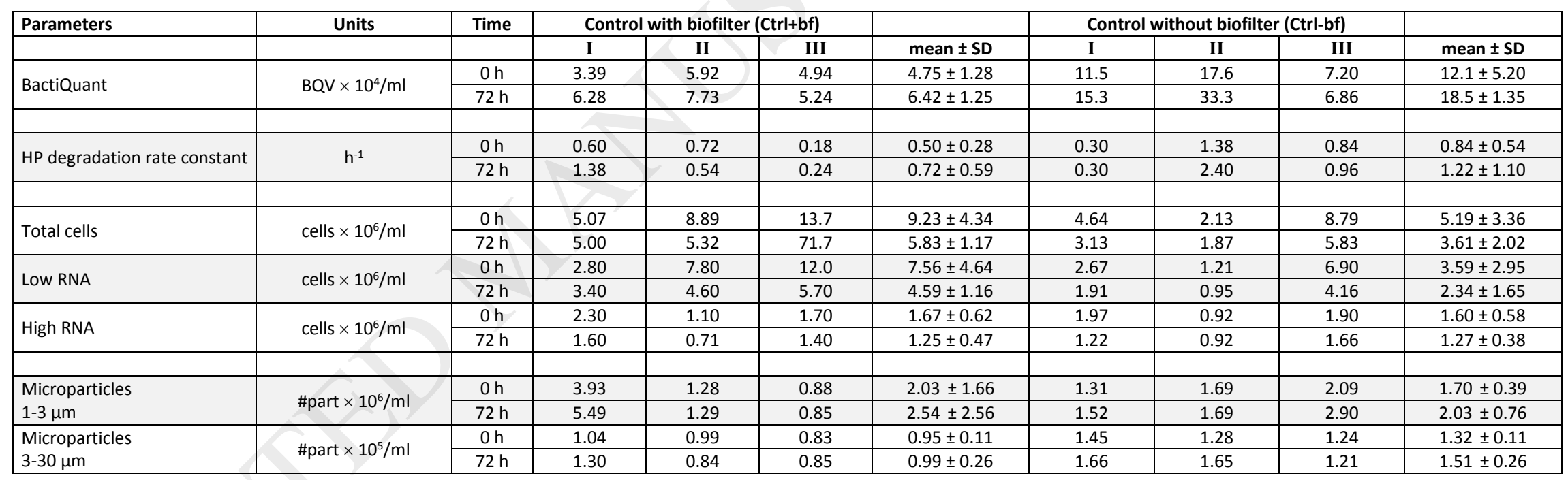

Table 5: Microbial water quality parameters for RAS groups with added acetate.

\begin{tabular}{|c|c|c|c|c|c|c|c|c|c|c|}
\hline \multirow[t]{2}{*}{ Parameters } & \multirow[t]{2}{*}{ Units } & \multirow[t]{2}{*}{ Time } & \multicolumn{3}{|c|}{ Acetate with biofilter (Ac+bf) } & \multicolumn{5}{|c|}{ Acetate without biofilter (Ac-bf) } \\
\hline & & & I & II & III & mean $\pm S D$ & $\mathbf{I}$ & II & III & mean $\pm S D$ \\
\hline \multirow{2}{*}{ BactiQuant } & \multirow{2}{*}{$\mathrm{BQV} \times 10^{4} / \mathrm{ml}$} & $0 \mathrm{~h}$ & 3.72 & 3.68 & 12.1 & $6.51 \pm 4.86$ & 6.54 & 9.76 & 4.32 & $6.87 \pm 2.73$ \\
\hline & & $72 \mathrm{~h}$ & 2.10 & 3.08 & 10.5 & $5.24 \pm 4.61$ & 67.6 & 4.28 & 3.24 & $25.0 \pm 36.9$ \\
\hline \multirow{2}{*}{ HP degradation rate constant } & \multirow{2}{*}{$h^{-1}$} & $\mathrm{Oh}$ & 0.18 & 1.62 & 0.90 & $0.90 \pm 0.72$ & 0.48 & 0.30 & 0.3 & $0.36 \pm 0.10$ \\
\hline & & $72 \mathrm{~h}$ & 0.24 & 1.32 & 0.90 & $0.82 \pm 0.54$ & 1.80 & 0.36 & 0.36 & $0.84 \pm 0.83$ \\
\hline \multirow{2}{*}{ Total Cells } & \multirow{2}{*}{ cells $\times 10^{6} / \mathrm{ml}$} & $\mathrm{Oh}$ & 4.63 & 17.0 & 5.95 & $9.10 \pm 6.88$ & 6.66 & 6.92 & 4.23 & $5.94 \pm 1.48$ \\
\hline & & $72 \mathrm{~h}$ & 4.05 & 24.1 & 9.81 & $1.26 \pm 1.03$ & 18.7 & 3.23 & 7.46 & $9.79 \pm 7.98$ \\
\hline \multirow{2}{*}{ Low RNA } & \multirow{2}{*}{ cells $\times 10^{6} / \mathrm{ml}$} & $\mathrm{Oh}$ & 3.63 & 12.0 & 4.34 & $6.51 \pm 4.38$ & 5.67 & 5.96 & 3.92 & $5.18 \pm 1.10$ \\
\hline & & $72 \mathrm{~h}$ & 3.50 & 17.0 & 7.68 & $9.38 \pm 6.89$ & 8.95 & 2.75 & 6.84 & $6.18 \pm 3.15$ \\
\hline \multirow{2}{*}{ High RNA } & \multirow{2}{*}{ cells $\times 10^{6} / \mathrm{ml}$} & $\mathrm{Oh}$ & 0.73 & 5.45 & 1.61 & $2.60 \pm 2.51$ & 1.00 & 0.96 & 0.32 & $0.76 \pm 0.38$ \\
\hline & & $72 \mathrm{~h}$ & 0.55 & 7.09 & 2.14 & $3.26 \pm 3.41$ & 9.73 & 0.48 & 0.62 & $3.61 \pm 5.30$ \\
\hline \multirow{4}{*}{$\begin{array}{l}\text { Microparticles } \\
1-3 \mu \mathrm{m} \\
\text { Microparticles } \\
3-30 \mu \mathrm{m}\end{array}$} & \multirow{2}{*}{ \#part $\times 10^{6} / \mathrm{ml}$} & $\mathrm{Oh}$ & 1.07 & 7.23 & 2.09 & $3.47 \pm 3.30$ & 1.06 & 1.16 & 0.60 & $0.94 \pm 0.30$ \\
\hline & & $72 \mathrm{~h}$ & 7.11 & 7.00 & 2.26 & $3.32 \pm 3.28$ & 4.72 & 1.43 & 1.40 & $2.52 \pm 1.91$ \\
\hline & \multirow{2}{*}{ \#part $\times 10^{5} / \mathrm{ml}$} & $\mathrm{Oh}$ & 0.97 & 0.88 & 2.05 & $1.30 \pm 0.65$ & 0.65 & 0.79 & 0.63 & $0.68 \pm 0.08$ \\
\hline & & $72 \mathrm{~h}$ & 0.75 & 0.87 & 1.13 & $0.91 \pm 0.19$ & 0.64 & 0.72 & 2.81 & $1.39 \pm 1.23$ \\
\hline
\end{tabular}


